\title{
Silver-doped graphene oxide nanocomposite triggers cytotoxicity and apoptosis in human hepatic normal and carcinoma cells
}

This article was published in the following Dove Press journal: International Journal of Nanomedicine

\section{Daoud Ali}

Saud Alarifi

Saad Alkahtani

Rafa S Almeer

Department of Zoology, College of Science, King Saud University, Riyadh, Saudi Arabia
Correspondence: Saud Alarifi Department of Zoology, College of Science, King Saud University, PO Box 2455, Riyadh II45I, Saudi Arabia

Tel +966 I46798I6

Fax+966I46785I4

Email salarifi@ksu.edu.sa
Introduction: Graphene oxide nanoparticles have been widely used in industry and biomedical fields due to their unique physicochemical properties. However, comparative cytotoxicity of silver-doped reduced graphene oxide ( $\mathrm{rGO}-\mathrm{Ag}$ ) nanoparticles on normal and cancerous liver cells has not been well studied yet.

Materials and methods: This study aimed at determining the toxic potential of $\mathrm{rGO}-\mathrm{Ag}$ nanocomposite on human liver normal (CHANG) and cancer (HepG2) cells. The rGO-Ag nanocomposite was characterized by using different advanced instruments, namely, dynamic light scattering, scanning electron microscope, and transmission electron microscope.

Results: The rGO-Ag nanocomposite reduced cell viability and impaired cell membrane integrity of CHANG and HepG2 cells in a dose-dependent manner. Additionally, it induced reactive oxygen species generation and reduced mitochondrial membrane potential in both cells in a dose-dependent manner. Moreover, the activity of oxidative enzymes such as lipid peroxide, superoxide dismutase, and catalase were increased and glutathione was reduced in both cells exposed to rGO-Ag nanocomposite. Pretreatment with $\mathrm{N}$-acetylcysteine inhibited cytotoxicity and reactive oxygen species generation in CHANG and HepG2 cells exposed to rGO-Ag nanocomposite $(50 \mu \mathrm{g} / \mathrm{mL})$. DNA damage was determined by Comet assay and maximum DNA damage occurred at rGO-Ag nanocomposite $(25 \mu \mathrm{g} / \mathrm{mL})$ for $24 \mathrm{~h}$. It is also valuable to inform that HepG2 cells appear to be slightly more susceptible to $\mathrm{rGO}-\mathrm{Ag}$ nanocomposite exposure than CHANG cells.

Conclusion: This result provides a basic comparative toxic effect of $\mathrm{rGO}-\mathrm{Ag}$ nanocomposite on hepatic normal and cancerous liver cells.

Keywords: oxidative stress, CHANG and HepG2 cells, cytotoxicity, DNA fragmentation, apoptosis

\section{Introduction}

Nowadays, nanotechnology has become a necessary and important tool to form different kinds of nanomaterials with large surface area to volume ratios and unique properties. ${ }^{1}$ Graphene has developed as an extraordinary nanoscale carbon with unique properties. It is a two-dimensional planar with six carbon atoms. In graphene, carbon atoms are arranged in a honeycomb lattice with a thickness of a single atom. Graphene is useful in the field of bone tissue applications. ${ }^{2}$ Graphene oxide nanoparticles are useful in bone tissue engineering and cell growth. ${ }^{3} \mathrm{Ma}$ et $\mathrm{al}^{4}$ had used graphene nanoparticles to find out various types of cancer biomarkers. CA-125 (ovarian cancer biomarker) was distinguished using chemiluminescence resonance energy transfer to graphene nanoparticles. ${ }^{5}$ Silver nanoparticles (AgNPs) are usually used in different types of 
biomedical applications, including drug delivery, diagnostics, biomarkers, distinct antibacterial, antifungal, and anti-biofilm agents. ${ }^{6}$ AgNPs-decorated graphene oxide is the most promising for optoelectronics, catalysis, and electrochemistry applications; it also shows enhanced antibacterial activity. ${ }^{7-9}$

In spite of their benefits, current studies have reported the toxicological effects of silver-doped reduced graphene oxide (rGO-Ag) nanocomposite under certain conditions. In particular, toxicity of nanoparticles in various cells is governed by the interactions and distribution patterns of the nanoparticles. ${ }^{10}$ The size of nanoparticles impacts on the binding and activation of membrane receptors and consequent protein expression in cancer cells. ${ }^{11}$ Silver nanoparticles induced cell death and decreased cell viability of different types of cell lines by inducing apoptosis through the mitochondrial pathway and generation of reactive oxygen species (ROS). ${ }^{12,13}$ Human normal and cancerous liver cells appear to be an excellent in vitro model for toxic experiments due to their deficiency of infection and ability of multiplying in culture for longer durations. The purpose of this experiment was to identify the mechanism of comparative toxicity of $\mathrm{rGO}-\mathrm{Ag}$ nanocomposite in the human liver normal (CHANG) and cancer (HepG2) cells.

\section{Materials and methods Chemical and reagents}

The rGO-Ag nanocomposite was obtained from the US Research Nanomaterial Inc. (Houston, TX, USA). The 5, 5-dithio-bis-(2-nitrobenzoic acid) (DTNB), MTT, lactate dehydrogenase (LDH) cytotoxicity assay kit (Cayman item no 601170), 2, 7-dichlorofluorescein diacetate (H2-DCFH-DA), DMSO, Annexin V-FITC, and propidium iodide (PI) were obtained from Sigma-Aldrich (St Louis, MO, USA). DMEM, fetal bovine serum (FBS), and antibiotics were purchased from Thermo Fisher Scientific (Waltham, MA, USA). All other chemicals were purchased from local suppliers.

\section{Cell culture and nanoparticles exposure}

CHANG and HepG2 cells were bought from American Type Culture Collection (Manassas, VA, USA). Both the cells were grown in DMEM culture medium supplemented with FBS $(10 \%)$ and $100 \mathrm{U} / \mathrm{mL}$ antibiotics at $\mathrm{CO}_{2}(5 \%)$ incubator at $37^{\circ} \mathrm{C}$. At $\sim 80 \%$ confluence, both the cells were subcultured into 96-well plates, 6-well plates, and $25 \mathrm{~cm}^{2}$ flasks according to designed experiments. The cells were precultured for $24 \mathrm{~h}$ before exposure to $\mathrm{rGO}-\mathrm{Ag}$ nanocomposite. The nanocomposite powder was suspended in culture medium ( $1 \mathrm{mg} / \mathrm{mL}$ ) and diluted according to the experimental concentrations $(5-50 \mu \mathrm{g} / \mathrm{mL})$. The suspension solution of $\mathrm{rGO}-\mathrm{Ag}$ nanocomposite was sonicated by using probe sonicator at room temperature for $15 \mathrm{~min}$ at $40 \mathrm{~W}$ to avoid nanoparticles' aggregation before treatment. The CHANG and HepG2 cells were exposed for $60 \mathrm{~min}$ to $5 \mathrm{mM}$ of $N$-acetylcysteine (NAC) before 24-h coexposure with or without $\mathrm{GGO}-\mathrm{Ag}$ nanocomposite. The cells that were not treated with $\mathrm{rGO}-\mathrm{Ag}$ nanocomposite served as controls in each experiment.

\section{Characterization of $\mathrm{rGO}-\mathrm{Ag}$ nanocomposite}

\section{Electron microscopy characterization of $\mathrm{rGO}-\mathrm{Ag}$ nanocomposite}

The size, shape, and morphology of rGO-Ag nanocomposite were observed by scanning electron microscope (SEM) and transmission electron microscope (TEM). The dry powder of rGO-Ag nanocomposite was mixed in double distilled water at $1 \mathrm{mg} / \mathrm{mL}$ and homogenous suspension was formed after sonicating by a Q700 sonicator (Qsonica L.L.C, Newtown, CT, USA) at room temperature for $15 \mathrm{~min}$ at $40 \mathrm{~W}$. Next, a drop of diluted rGO-Ag nanocomposite suspension was put onto a carbon-coated copper grid, air dried, and observed with TEM.

\section{EDX observation of $\mathrm{rGO}-\mathrm{Ag}$ nanocomposite}

The energy-dispersive X-ray (EDX) analysis was done by using a high-resolution TEM (JEM-2100; JEOL Ltd., Tokyo, Japan) to check the presence of graphene oxide and silver in the particles as well as to detect other elementary compositions of the particles.

\section{Characterization of rGO-Ag nanocomposite by dynamic light scattering (DLS)}

The mean hydrodynamic size and zeta potential of $\mathrm{rGO}-\mathrm{Ag}$ nanocomposite in culture medium and distilled water were observed by DLS (Nano-ZetaSizer-HT; Malvern Panalytical, Malvern, UK) as reported by Murdock et al. ${ }^{14}$ The dry powder of $\mathrm{rGO}-\mathrm{Ag}$ nanocomposite was suspended in distilled water and cell culture medium (DMEM with 10\% FBS) at a concentration of $50 \mu \mathrm{g} / \mathrm{mL}$. Then, the suspension was sonicated using a sonicator at room temperature for $15 \mathrm{~min}$ at $20 \mathrm{~W}$, and the hydrodynamic size was determined. We have used the $\mathrm{rGO}-\mathrm{Ag}$ nanocomposite $(50 \mu \mathrm{g} / \mathrm{mL})$ for hydrodynamic size examination because it is the highest treatment level used in cytotoxicity studies.

\section{Cell morphology}

CHANG and HepG2 cells $\left(1 \times 10^{4} /\right.$ well) were seeded in 6-well plates, and after $24 \mathrm{~h}$, the cells were exposed to rGO-Ag nanocomposite $(0,5,10,25$, and $50 \mu \mathrm{g} / \mathrm{mL})$ for 
$24 \mathrm{~h}$. Morphology of both the cells was observed after 24-h exposure by using an inverted microscope (Leica DMIL, Houston, TX, USA).

\section{MTT assay}

The cytotoxicity of $\mathrm{rGO}-\mathrm{Ag}$ nanocomposite on $\mathrm{CHANG}$ and HepG2 cells was measured as described by Mosmann ${ }^{15}$ with little modification. ${ }^{16}$ Briefly, $1 \times 10^{4}$ cells per well were cultured in culture plates (96-well) and treated with various doses $(0,5,10,25$, and $50 \mu \mathrm{g} / \mathrm{mL})$ of $\mathrm{rGO}-\mathrm{Ag}$ nanocomposite for $24 \mathrm{~h}$. After exposure, the culture medium was removed from 96-well plates and changed with culture medium with MTT solution (5\%) and put for $210 \mathrm{~min}$ at $37^{\circ} \mathrm{C}$ until a violetcolored formazan product formed. The formazan crystal was dissolved in dimethyl sulfoxide. After dissolving the crystal, the absorbance was measured at $570 \mathrm{~nm}$ using a microplate reader (Synergy-HT; BioTek, Winooski, VT, USA).

\section{$\mathrm{LDH}$ assay}

LDH enzyme leakage was measured by using Cayman Chemical LDH assay kit (Item No 601170; Cayman Chemical, Ann Arbor, MI, USA) according to the manufacturer's protocol. Briefly, $1 \times 10^{4}$ cells per well were plated in 96-well plates and treated with different doses of $\mathrm{rGO}-\mathrm{Ag}$ nanocomposite $(0,5,10,25$, and $50 \mu \mathrm{g} / \mathrm{mL})$ for $24 \mathrm{~h}$. After treatment, the culture plates were centrifuged at $2,000 \times g$ for $5 \mathrm{~min}$ to settle the NPs present in the solution.

The cell lysate $(100 \mu \mathrm{L})$ was transferred to new 96-well plates and the reaction mixture $(100 \mu \mathrm{L})$ from the kit was added and the culture plates were incubated for $30 \mathrm{~min}$ at room temperature. After incubation, we determined the OD at $340 \mathrm{~nm}$ by using microplate reader (Synergy-HT; BioTek). The level of LDH in culture medium vs in the cells was examined and compared with the control data according to the manufacturer's instructions.

\section{Reactive oxygen species}

The production of intracellular ROS in both the cells due to exposure to $\mathrm{rGO}-\mathrm{Ag}$ nanocomposite for $24 \mathrm{~h}$ was determined by using DCFH-DA as described by Alarifi et al. ${ }^{17}$ The cells $\left(1 \times 10^{4}\right)$ were seeded in 96-well black-bottom culture plates and allowed to adhere for $24 \mathrm{~h}$ in a $\mathrm{CO}_{2}$ incubator at $37^{\circ} \mathrm{C}$. After treatment, the cells were washed three times with chilled PBS before adding $100 \mu \mathrm{L}$ of working solution of $10 \mu \mathrm{M}$ DCFH-DA per well at $37^{\circ} \mathrm{C}$ for $60 \mathrm{~min}$. Again, the cells were washed with PBS, and fluorescence was measured at $485 \mathrm{~nm}$ excitation and $520 \mathrm{~nm}$ emissions using the microplate reader (Synergy-HT; BioTek). The values were expressed as percent of fluorescence intensity relative to the control wells.

An analogous set of cells $\left(1 \times 10^{3}\right.$ cells/well in a 6 -well transparent plate) was analyzed for intracellular fluorescence using a fluorescence microscope (Olympus CKX41; Olympus, Center Valley, PA, USA), with images taken at $10 \times$ magnification.

\section{Cell lysate}

The cell lysate was formed from control and $\mathrm{rGO}-\mathrm{Ag}$ nanocomposite exposed cells for oxidative stress biomarker, namely, lipid peroxide (LPO), glutathione (GSH), superoxide dismutase (SOD), and catalase (CAT). In brief, both the cells were grown in $25 \mathrm{~cm}^{2}$ culture flask and treated with different concentrations of $\mathrm{rGO}-\mathrm{Ag}$ nanocomposite $(5-50 \mu \mathrm{g} / \mathrm{mL})$ for $24 \mathrm{~h}$. After exposure, the cells were scraped and washed with PBS at $4^{\circ} \mathrm{C}$. The cell pellets were then lysed in cell lysis buffer $(1 \times 20 \mathrm{mM}$ Tris- $\mathrm{HCl}$ [pH 7.5], $150 \mathrm{mM} \mathrm{NaCl}, 1 \mathrm{mM}$ $\mathrm{Na}_{2}$ EDTA, 1\% Triton, $2.5 \mathrm{mM}$ sodium pyrophosphate). After centrifugation $\left(13,000 \times g\right.$ for $10 \mathrm{~min}$ at $\left.4^{\circ} \mathrm{C}\right)$, the supernatant (cell extract) was maintained on ice for further assays.

\section{Lipid peroxide test}

The level of LPO was determined by measuring the malondialdehyde (MDA) formed using the method of Ohkawa et al. ${ }^{18}$ The cell lysate $(100 \mu \mathrm{L})$ was mixed with $1.9 \mathrm{~mL}$ of sodium phosphate buffer $(0.1 \mathrm{M}, \mathrm{pH} 7.4)$ and incubated for $60 \mathrm{~min}$ at $37^{\circ} \mathrm{C}$. After incubation, $5 \%$ trichloroacetic acid (TCA) was added and centrifuged at $3,000 \times g$ for $10 \mathrm{~min}$ at room temperature to obtain a supernatant. The supernatant was mixed with $1 \mathrm{~mL}$ thiobarbituric acid (1\%) and put in a water bath at $100^{\circ} \mathrm{C}$ for $30 \mathrm{~min}$. The OD of the cooled mixture was examined at $532 \mathrm{~nm}$ and was converted to MDA and expressed in terms of percentage when compared with the control.

\section{Glutathione assay}

The GSH level was measured using Ellman's method. ${ }^{19}$ The cell lysate $(100 \mu \mathrm{L})$ was mixed with $900 \mu \mathrm{L}$ TCA $(5 \%)$ and centrifuged at $3,000 \times g$ for $10 \mathrm{~min}$ at $4{ }^{\circ} \mathrm{C}$. The supernatant $(500 \mu \mathrm{L})$ was mixed with DTNB $(0.01 \%, 1.5 \mathrm{~mL})$, and the reaction was observed at $412 \mathrm{~nm}$. The quantity of GSH was represented in terms of percentage when compared with the control.

\section{Superoxide dismutase}

The SOD level was measured according to the method of Ali et al. ${ }^{20}$ After exposure to $\mathrm{rGO}-\mathrm{Ag}$ nanocomposite 
$(0,5,10,25$, and $50 \mu \mathrm{g} / \mathrm{mL})$, the cells were harvested and lysed in lysis buffer at $4{ }^{\circ} \mathrm{C}$. The reaction mixture $(2.1 \mathrm{~mL})$ contained $1.9 \mathrm{~mL}$ sodium carbonate buffer $(50 \mathrm{mM}), 30 \mu \mathrm{L}$ nitro blue tetrazolium (1.6 mM), $6 \mu \mathrm{L}$ Triton X-100 (10\%), and $20 \mu \mathrm{L}$ hydroxylamine-HCl (100 mM). Subsequently, $100 \mu \mathrm{L}$ cell lysate was mixed and absorbance was taken at $560 \mathrm{~nm}$ for $5 \mathrm{~min}$ against a blank (reaction mixtures and cell extract). In this experiment, a specific control containing reaction mixture with cell extract (unexposed cells) was also run.

\section{Catalase}

The activity of CAT was determined by using the method of Aebi. ${ }^{21}$ After exposure to $\mathrm{rGO}-\mathrm{Ag}$ nanocomposite $(0,5,10$, 25 , and $50 \mu \mathrm{g} / \mathrm{mL}$ ), the cells were harvested, and cell lysate was prepared by lysing the crude extract in cell lysis buffer. In this, absorbance $(240 \mathrm{~nm})$ of $1 \mathrm{~mL}$ reaction mixture containing $0.8 \mathrm{~mL} \mathrm{H}_{2} \mathrm{O}_{2}$ phosphate buffer $\left(\mathrm{H}_{2} \mathrm{O}_{2}\right.$ diluted 500 folds with $0.1 \mathrm{M}$ phosphate buffer of $\mathrm{pH} 7), 100 \mu \mathrm{L}$ cell extract, and $100 \mu \mathrm{L}$ distilled water was recorded for 4 min against a blank $\left(\mathrm{H}_{2} \mathrm{O}_{2}\right.$ phosphate buffer).

\section{Mitochondrial membrane potential (MMP) test}

The MMP was observed according to the protocol of Sakamuru et al. ${ }^{22}$ Both the cells $\left(5 \times 10^{4}\right.$ cells per well $)$ were exposed to different concentrations of $\mathrm{rGO}-\mathrm{Ag}$ nanocomposite for $24 \mathrm{~h}$. After exposure, the cells were washed with chilled PBS and again exposed to Rhodamine-123 fluorescent stain for $60 \mathrm{~min}$ at $37^{\circ} \mathrm{C}$ in the dark. The cells were washed with chilled PBS, and the fluorescent intensity of the Rh-123 stain was examined at $488 \mathrm{~nm}$ in an upright fluorescence microscope (Olympus CKX41) by capturing the images at $20 \times$ magnification.

We have examined the loss of MMP by Rhodamine-123. $1 \times 10^{4}$ cells/well in a 96-well plate were cultured, and the loss of MMP was analyzed at $488 \mathrm{~nm}$ (excitation wavelength) and $530 \mathrm{~nm}$ (emission wavelength) by using the microplate reader (Synergy-HT; BioTek).

\section{Assessment of caspase- 3 enzyme and chromosome fragmentation}

The caspase-3 enzyme was measured in CHANG and HepG2 cells after exposure to $\mathrm{rGO}-\mathrm{Ag}$ nanocomposite for $24 \mathrm{~h}$ by using Biovision colourimetric assay kits (BioVision, Inc., Milpitas, CA, USA). After exposure to rGO-Ag nanocomposite for $24 \mathrm{~h}$, the cell lysate was prepared. This assay is based on the principle that activated caspases in apoptotic cells cleave the synthetic substrates to release free chromophore p-nitroanilide (pNA), which is measured at $405 \mathrm{~nm}$. The pNA was produced after reaction of caspase- 3 on tetrapeptide substrates DEVD-pNA. Briefly, cell lysate protein $(50 \mu \mathrm{L})$, reaction buffer with $10 \mathrm{mM}$ dithiothreitol $(50 \mu \mathrm{L}$, $2 \mathrm{X})$ and $4 \mathrm{mM}$ DEVD-pNA ( $5 \mu \mathrm{L}$, for caspase-3) substrate were mixed. The reaction mixture was put at $37^{\circ} \mathrm{C}$ for $1 \mathrm{~h}$, and the absorbance of the product was measured using the microplate reader (Synergy-HT; BioTek) at $405 \mathrm{~nm}$ according to the manufacturer's protocol.

The qualitative analysis of normal and condensed chromatin in cells was performed through the Hoechst 33342 staining test, and apoptosis is based on nuclear fragmentation and condensation. After exposure to $\mathrm{rGO}-\mathrm{Ag}$ nanocomposite for $24 \mathrm{~h}$, the cells were incubated with a mixture of Hoechst $33342(10 \mu \mathrm{L})$. After $30 \mathrm{~min}$ incubation, the cells were washed three times with normal PBS. The condensed chromosome was observed by using fluorescence images in the upright microscope (Nikon Eclipse; Nikon Corporation, Tokyo, Japan).

\section{Analysis of cellular apoptosis}

Both the cells $\left(5 \times 10^{4}\right.$ cells per well $)$ were seeded into 6-well plates and incubated for $24 \mathrm{~h}$ at $37^{\circ} \mathrm{C}$ under an atmosphere of $5 \% \mathrm{CO}_{2}$. The different concentration of $\mathrm{rGO}-\mathrm{Ag}$ nanocomposite was treated. After incubation for $24 \mathrm{~h}$, the treated cells were trypsinized and washed with PBS twice and centrifuged at $300 \times g$ to collect the cells. The binding buffer $(500 \mathrm{~mL})$ was used to suspend the cells. Then, $5 \mu \mathrm{L}$ of Annexin V-FITC and $10 \mu \mathrm{L}$ of PI were mixed successively and mixed very well. The cells were incubated for $15 \mathrm{~min}$ at room temperature in dark, and the cell apoptosis was analyzed with flow cytometry (FACS Calibur Becton-Dickinson).

\section{Quantitative real-time PCR analysis}

The cells were subcultured in a small culture flask $\left(25 \mathrm{~cm}^{2}\right)$ and treated with $\mathrm{rGO}-\mathrm{Ag}$ nanocomposite $(25 \mu \mathrm{g} / \mathrm{mL})$ for $24 \mathrm{~h}$. The total RNA was extracted from exposed cells by using the Qiagen RNeasy Mini Kit (Qiagen, Germantown, MD, USA) according to the manufacturer's instructions. The quantity of RNA was measured by using a Nanodrop 8000 spectrophotometer (Thermo Fisher Scientific). We have synthesized cDNA from RNA $(1 \mu \mathrm{g})$ by the reverse transcriptase and applied M-MLV (Promega, Madison, WI, USA) and oligo (dT) primers (Promega) as described in the manufacturer's protocol.

The real-time polymerase chain reaction (PCR) was done by applying the QuantiTect SYBR Green PCR kit (Qiagen) using the ABI PRISM 7900HT Sequence 
Detection System (Applied Biosystems, Foster City, CA, USA). The template cDNA $(2 \mu \mathrm{L})$ was mixed with the reaction mixture $(20 \mu \mathrm{L})$. Real-time PCR cycle have $10 \mathrm{~min}$ at $95^{\circ} \mathrm{C}$ followed by 40 cycles involving denaturation at $95^{\circ} \mathrm{C}$ for $15 \mathrm{~s}$, annealing at $60^{\circ} \mathrm{C}$ for $20 \mathrm{~s}$, and elongation at $72^{\circ} \mathrm{C}$ for $20 \mathrm{~s}$.

PCR analysis was done using primer sequences of apoptotic genes such as Bax, bcl2, and caspase-3, and $\beta$-actin expression was used as a control. Gene-specific primer sequences are below:

$\beta$ - A c t in - F - C C A A C C G C G A G A A G A T G A, R-CCAGAGGCGTACAGGGATAG

B a x - F - T T C A T C C A G G A T C G A G C A G G, R-TGAGACACTCGCTCAGCTTC

Bcl2-F-TGGACAACCATGACCTTGGACAATCA, R-TCCATCCTCCACCAGTGTTCCCATC Caspase-3-F-AGGACTCTAGACGGCATCCA, R-CAGTGAGACTTGGTGCAGTGA.

The selected gene expression was normalized to the $\beta$-actin gene, which was used as an internal housekeeping control.

\section{Comet assay}

Comet assay is a qualitative and quantitative assay for determining DNA strand breakage in single cells. ${ }^{23}$ Both the cells $\left(5 \times 10^{5}\right.$ cells/well) were cultured in 6 -well culture plates for $24 \mathrm{~h}$. After $24 \mathrm{~h}$, the old culture medium was replaced by a new one with $\mathrm{rGO}-\mathrm{Ag}$ nanocomposite $(0,10,25$, and $50 \mu \mathrm{g} / \mathrm{mL}$ ) added to culture medium and incubated at $37^{\circ} \mathrm{C}$ for $24 \mathrm{~h}$ in the $\mathrm{CO}_{2}$ incubator. After exposure, the cells were trypsinized and centrifuged at 1,200 rpm for $5 \mathrm{~min}$ at $4^{\circ} \mathrm{C}$. A total of 200 comets on each slide were visually scored according to the intensity of fluorescence in the tail and analyzed by using an image analysis system (Komet-5.5; Kinetic Imaging Ltd., Liverpool, UK) attached to a fluorescent microscope (Leica Microsystems, Wetzlar, Germany) equipped with appropriate filters.

\section{Protein assay}

Protein quantity in cell lysis was determined by Bradford method ${ }^{24}$ using bovine serum albumins as the standard.

\section{Statistical analysis}

The statistical differences were determined by analysis of variance, and the significant and highly significant differences were noted at $p<0.05$ and $p<0.01$, respectively. The data are expressed as average of three independent experimental points.

\section{Results \\ Characterization of $\mathrm{rGO}-\mathrm{Ag}$ nanocomposite}

We have characterized $\mathrm{rGO}-\mathrm{Ag}$ nanocomposite by SEM, TEM, and DLS methods. The SEM image indicates surface morphology of graphene oxide (Figure 1A) and $\mathrm{rGO}-\mathrm{Ag}$ nanoparticle (Figure 1B). The average size of graphene oxide and silver nanoparticles are $100 \pm 2.5$ and $16.0 \pm 2 \mathrm{~nm}$, respectively. The TEM images revealed the transparent and sheet-like structure of chemically reduced graphene oxide (Figure 1C). An enormous number of scrolls and wrinkles were observed on the surface of the chemically reduced graphene oxide nanoparticle. The silver nanoparticles were observed in the high-resolution TEM (Figure 1D). We have found carbon (as graphene) 67.62\% and silver element $17.92 \%$ in $\mathrm{rGO}-\mathrm{Ag}$ nanocomposite through EDX analysis (Figure 1E). Figure 1F represents the frequency of size distribution of $\mathrm{Ag}$ nanoparticle.

The size of $\mathrm{rGO}-\mathrm{Ag}$ nanocomposite in culture medium and double-distilled water was 194 and $217 \mathrm{~nm}$, respectively. Next, the zeta potential of $\mathrm{rGO}-\mathrm{Ag}$ nanocomposite in culture medium and water was -8 and $-13 \mathrm{mV}$, respectively.

\section{Morphology of CHANG and HepG2 cells and cytotoxicity}

The change in morphology of CHANG and HepG2 cells after exposure to $\mathrm{rGO}-\mathrm{Ag}$ nanocomposite for $24 \mathrm{~h}$ is presented in Figure 2. The figure shows that control cells are in spindle shape with high confluence, but exposed cells are detached from culture plate and become slightly round in shape.

The CHANG and HepG2 cells were treated with different concentrations $(5-50 \mu \mathrm{g} / \mathrm{mL})$ of $\mathrm{rGO}-\mathrm{Ag}$ nanocomposite for $24 \mathrm{~h}$ and the cytotoxicity was measured by the MTT and LDH assays. These tests indicate that $\mathrm{rGO}-\mathrm{Ag}$ nanocomposite $(5 \mu \mathrm{g} / \mathrm{mL})$ did not induce cytotoxicity in CHANG cells but slightly induced toxic effect in HepG2 cells. The $\mathrm{rGO}-\mathrm{Ag}$ nanocomposite induced cytotoxicity in a concentration-dependent manner. After exposure to rGO-Ag nanocomposite, MTT results showed that viabilities of CHANG cells were $96 \%, 84.9 \%, 68.7 \%$, and $35 \%$, while percent viabilities of HepG2 cells were 92\%, 78\%, 42.9\%, and $23 \%$ (Figure $3 \mathrm{~A}$ ).

In addition, we found LDH leakage in CHANG and HepG2 cells in a concentration-based manner after $\mathrm{rGO}-\mathrm{Ag}$ nanocomposite exposure. Leakage of LDH in CHANG cells raised up to $106 \%, 111.49 \%, 135.7 \%$, and $1,189 \%$, whereas in HepG2 cells, LDH leakage was increased to $109 \%, 120.90 \%$, $172 \%$, and $237 \%$ for the same concentrations of $5,10,25$, 

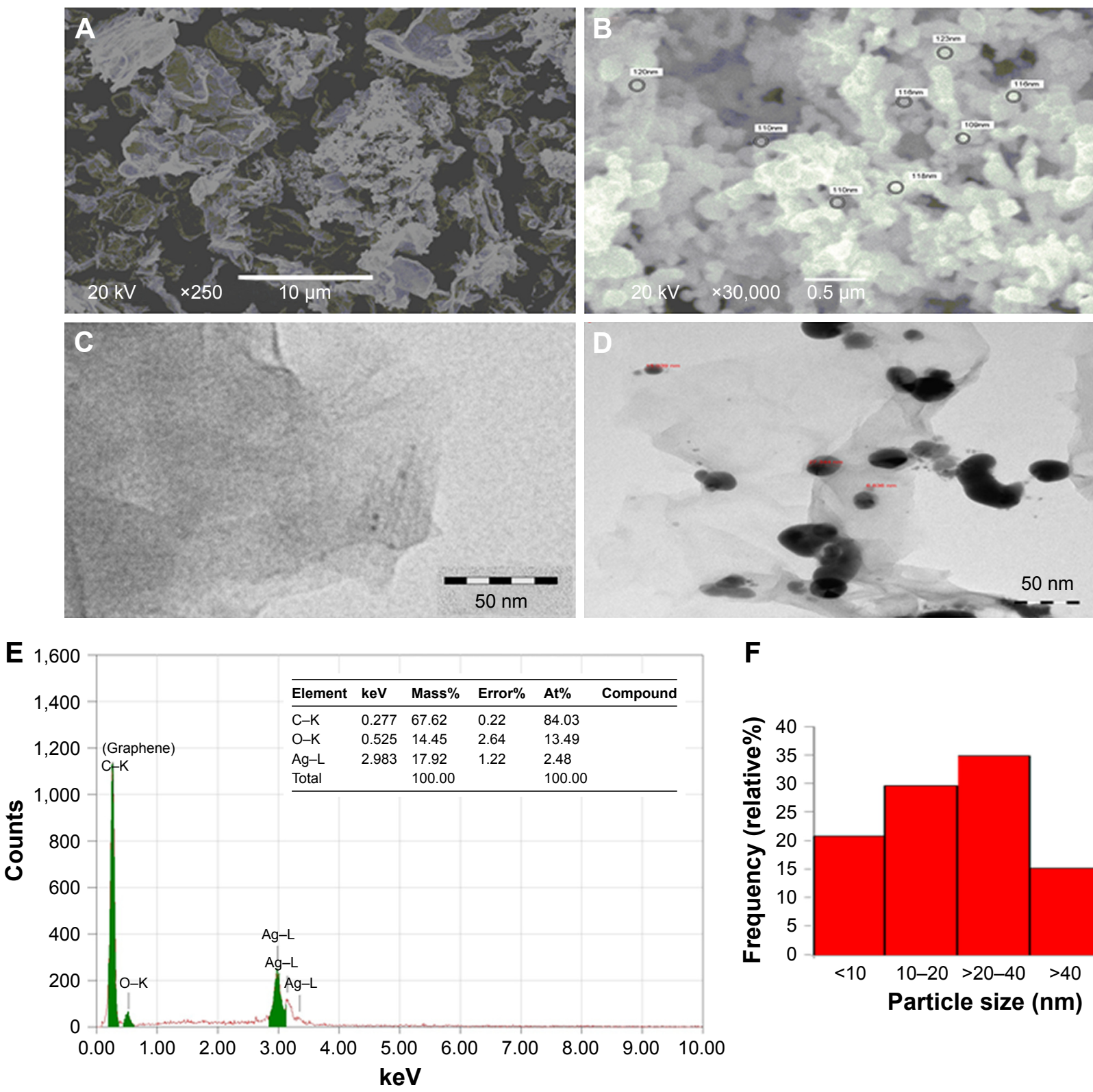

\section{$\mathbf{F}$}

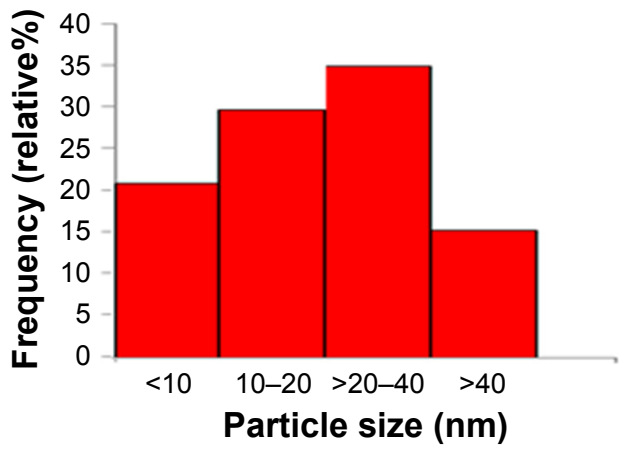

Figure I Electron microscopy characterization of rGO-Ag nanocomposite.

Notes: (A) SEM image of GO. (B) SEM image of rGO-Ag nanocomposite. (C) TEM image of GO. (D) TEM image of rGO-Ag nanocomposite. (E) EDX spectrum recorded showing sharp peak between 0 and $0.5 \mathrm{keV}$ and 2.7 and $4 \mathrm{keV}$ confirming the presence of carbon (graphene) and silver, respectively. (F) Frequency (\%) of Ag nanoparticle size distribution.

Abbreviations: At, atomic; EDX, energy-dispersive X-ray; rGO-Ag, silver-doped reduced graphene oxide; rGO-Ag, silver-doped reduced graphene oxide; SEM, scanning electron microscope; TEM, transmission electron microscope.

and $50 \mu \mathrm{g} / \mathrm{mL}$, respectively (Figure 3B). Moreover, a positive correlation was seen between cell viability and leakage of LDH in CHANG cells $\left(r^{2}=0.9834\right.$; Figure 3C) and HepG2 cells $\left(r^{2}=0.9509\right.$; Figure 3D).

\section{Oxidative stress}

Researchers reported that oxidative stress involved mutagenicity, apoptosis, and DNA damage. ${ }^{25,26}$ ROS generation due to $\mathrm{rGO}-\mathrm{Ag}$ nanocomposite in both cells was concentration dependent (Figure 4A and B). Fluorescent microscopy result demonstrated that the rGO-Ag nanocomposite-exposed cells show greater fluorescent DCF intensity (a biomarker of ROS production) in comparison to the untreated cells (Figure 4A). The MDA level, which is an end product of lipid peroxide, was highly significant, while the level of GSH was lowered significantly according to the dose-dependent manner in both cells (Figure 5A and B).

Figure $5 \mathrm{C}$ and D shows the levels of SOD and CAT activities in CHANG and HepG2 cells after treatment with rGO-Ag nanocomposite for $24 \mathrm{~h}$. In relation to the untreated 

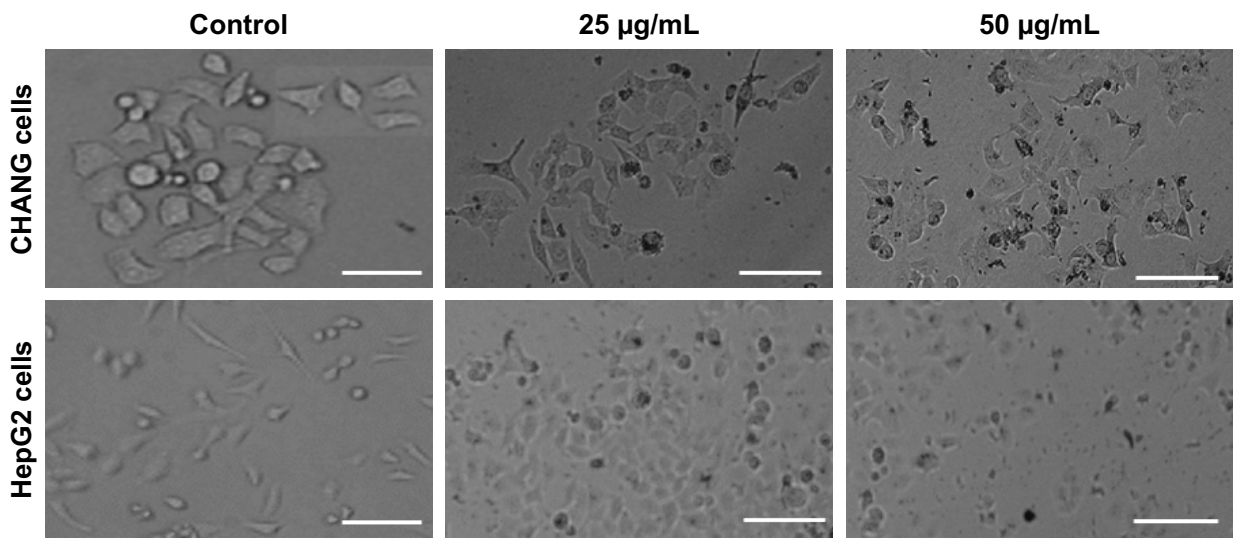

Figure 2 Morphological changes in CHANG and HepG2 cells exposed to different concentrations of rGO-Ag nanocomposite for $24 \mathrm{~h}$. Scale bar=50 $\mu \mathrm{m}$. Abbreviation: $\mathrm{rGO}-\mathrm{Ag}$, silver-doped reduced graphene oxide.

cells, the SOD activity was significantly increased in exposed cells at a concentration between 25 and $50 \mu \mathrm{g} / \mathrm{mL}$, while it had no effect on the SOD activity at lower doses when compared with the control. After 24-h exposure to $\mathrm{rGO}-\mathrm{Ag}$ nanocomposite, the enzyme activity of CAT increased in a dose-dependent manner but slightly decreased at a higher concentration in the CHANG and HepG2 cells (Figure 5D).
A

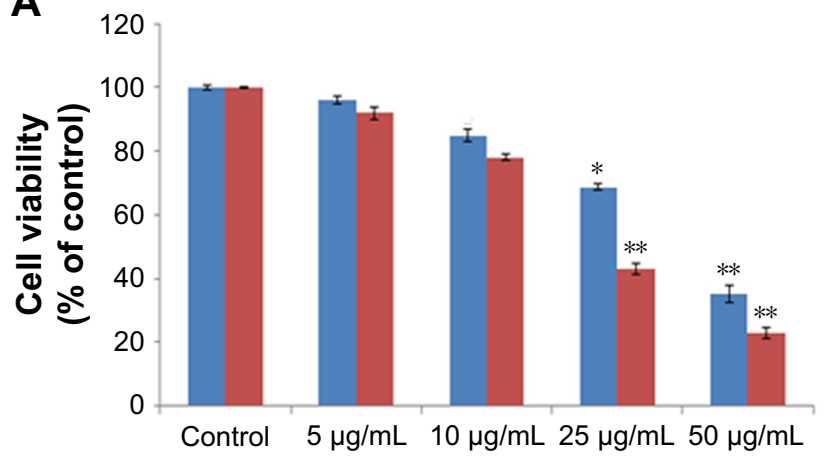

Concentration
B

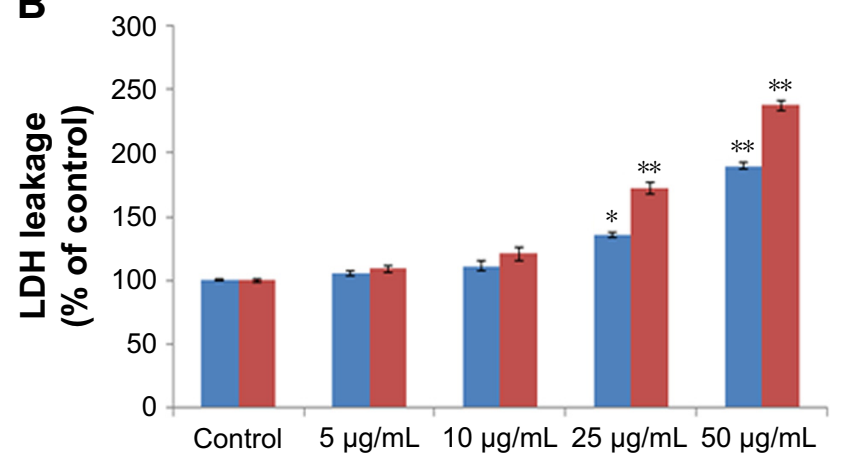

Concentration

CHANG cells HepG2 cells

C

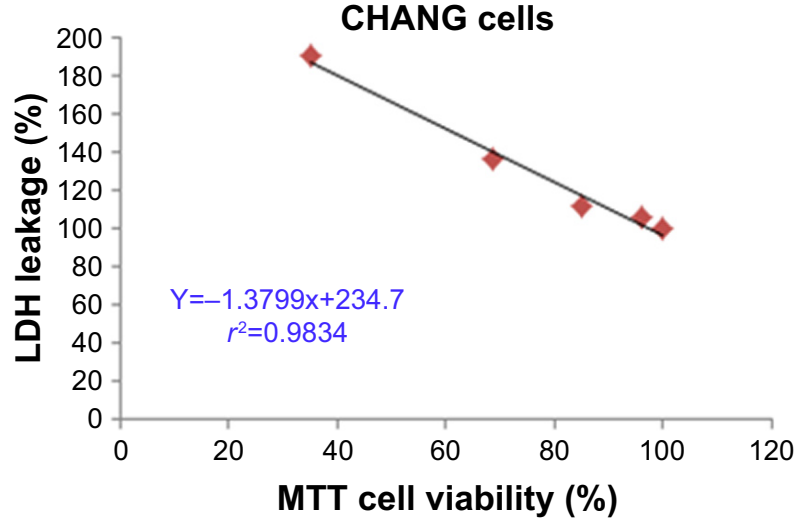

D $250 \quad$ HepG2 cells

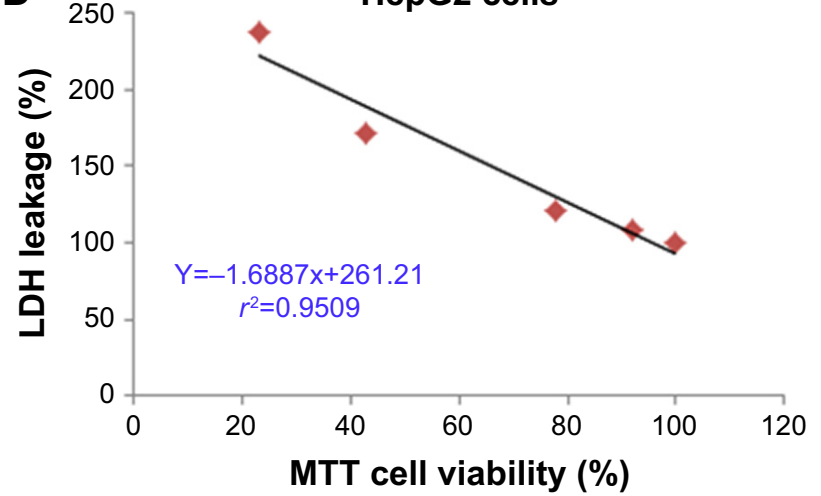

Figure 3 Cytotoxicity of $r G O-A g$ nanocomposite in CHANG and HepG2 cells for $24 \mathrm{~h}$, as determined by (A) MTT and (B) LDH tests. Each value represents the mean \pm SE of three experiments. $n=3, * p<0.05$ and ${ }^{* *} p<0.01$ vs control. A significant positive correlation between the LDH leakage and MTT cell viability in CHANG cells (C) and HepG2 cells (D) after rGO-Ag nanocomposite exposure.

Abbreviations: $\mathrm{rGO}-\mathrm{Ag}$, silver-doped reduced graphene oxide; LDH, lactate dehydrogenase; SE, standard error. 

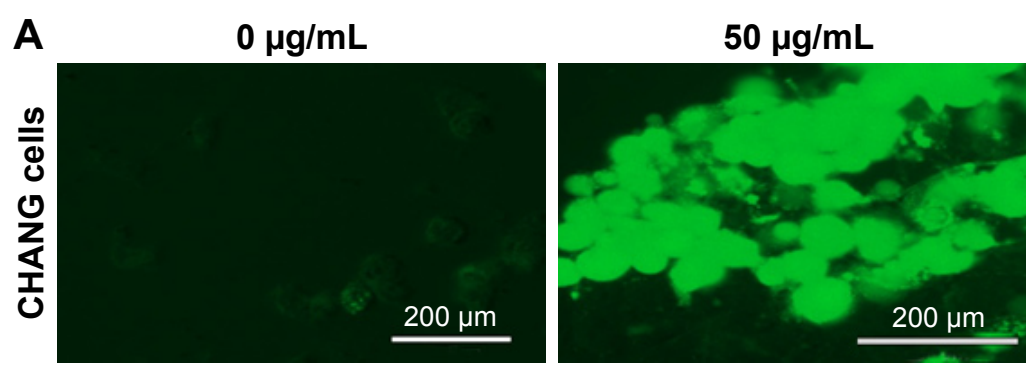

$50 \mu \mathrm{g} / \mathrm{mL}+1.5 \mathrm{mM} \mathrm{NAC}$
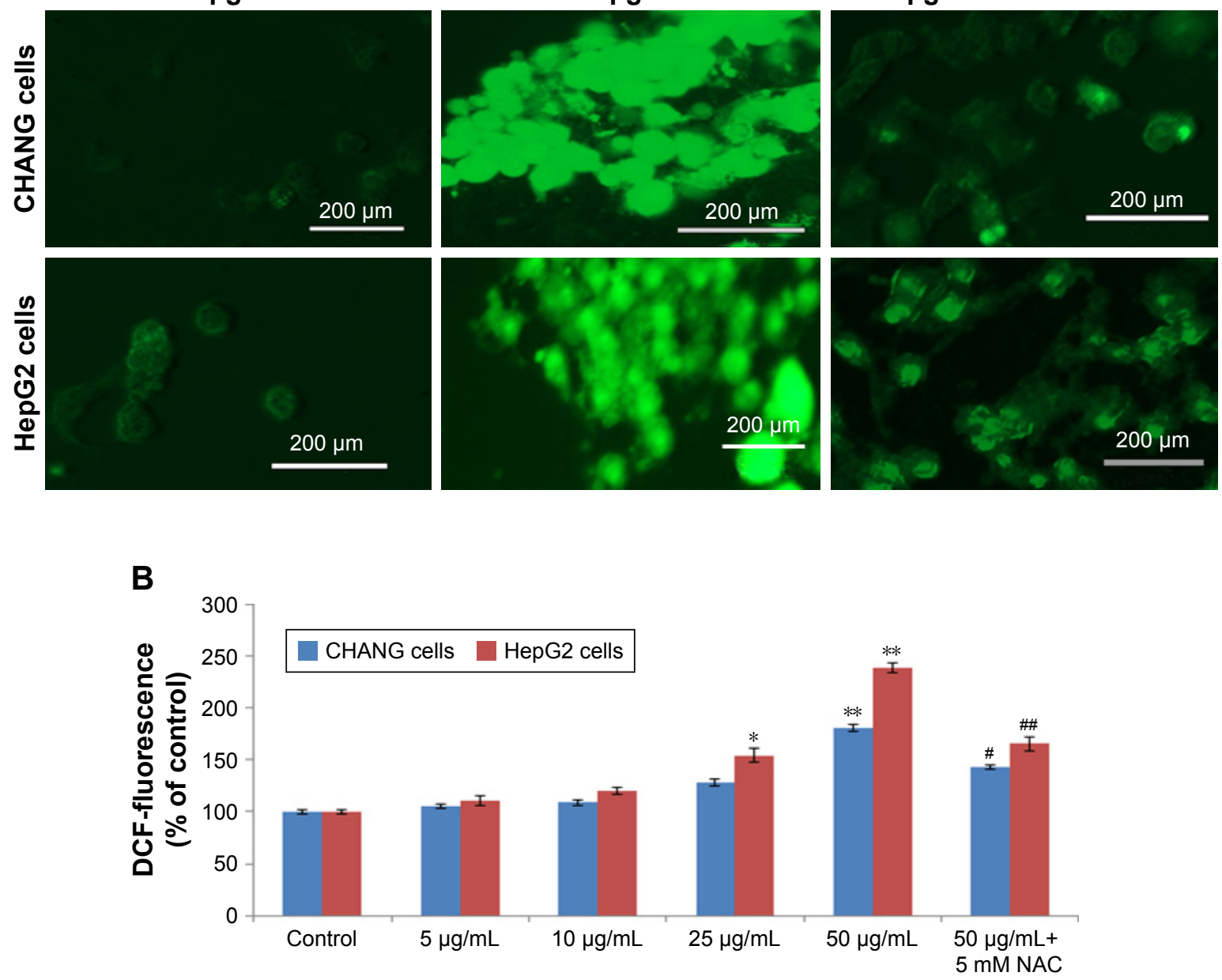

\section{Concentration}

Figure 4 ROS production induced by $\mathrm{rGO}-\mathrm{Ag}$ nanocomposite.

Notes: (A) The fluorescence image of CHANG and HepG2 cells treated with $50 \mu \mathrm{g} / \mathrm{mL}$ of rGO-Ag nanocomposite for $24 \mathrm{~h}$ and stained with DCFH-DA. (B) \% ROS production due to $\mathrm{rGO}-\mathrm{Ag}$ nanocomposite in cells. CHANG and HepG2 cells were pretreated with NAC ( $1.2 \mathrm{mM})$ for I h and then exposed to rGO-Ag nanocomposite $(50 \mu \mathrm{g} / \mathrm{mL})$ for $24 \mathrm{~h}$. Each value represents the mean \pm SE of three experiments. ${ }^{*} p<0.05$ and ${ }^{*} * p<0.01$ vs control. ${ }^{*} p<0.05$ and ${ }^{\#} p<0.01$ vs control and rGO-Ag nanocomposite $(50 \mu \mathrm{g} / \mathrm{mL})$.

Abbreviations: DCFH-DA, 2,7-dichlorofluoresceindiacetate; rGO-Ag, silver-doped reduced graphene oxide; NAC, N-acetylcysteine; ROS, reactive oxygen species; SE, standard error.

\section{Induction of MMP}

Webster ${ }^{27}$ had reported that MMP was decreased in apoptotic cell death. Fluorescence images were captured from fluorescence microscope, and it supported our quantitative data (Figure 6A-C). The low fluorescence intensity in the rGO-Ag nanocomposite-exposed cells demonstrates a significant loss of MMP (Figure 6C). In this experiment, we have observed that the rGO-Ag nanocomposite declined MMP in CHANG and HepG2 cells, and it was quantified in the form of fluorescence intensity of Rh-123 dye (Figure 6D).

\section{Induced apoptosis}

We analyzed mRNA level of various genes (Bax, bcl-2, and caspase-3) involved in the apoptosis in $\mathrm{rGO}-\mathrm{Ag}$ nanocomposite ( $50 \mu \mathrm{g} / \mathrm{mL}$ )-treated CHANG and HepG2 cells for $24 \mathrm{~h}$ by using quantitative real-time PCR. The rGO-Ag nanocomposite altered the regulation of genes in both cells. The preapoptotic gene Bax was upregulated while the antiapoptotic bcl 2 was downregulated in the cells.

Caspase-3 enzymes are the hallmark of apoptosis and are determined in nanocomposite exposed cells for confirmation of our real-time PCR data. The level of the caspase-3 enzyme was significantly increased in both the cells (Figure 7B).

The live cells exhibited normal intact nuclear chromatin with blue fluorescence, but apoptotic cells have fragmented chromatin. The rGO-Ag nanocomposite treatment described a significant number of apoptotic cells when compared with control (Figure 7A). 
A

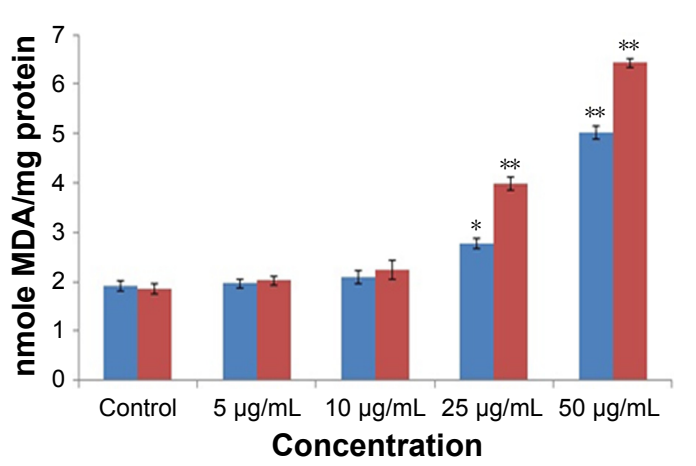

C

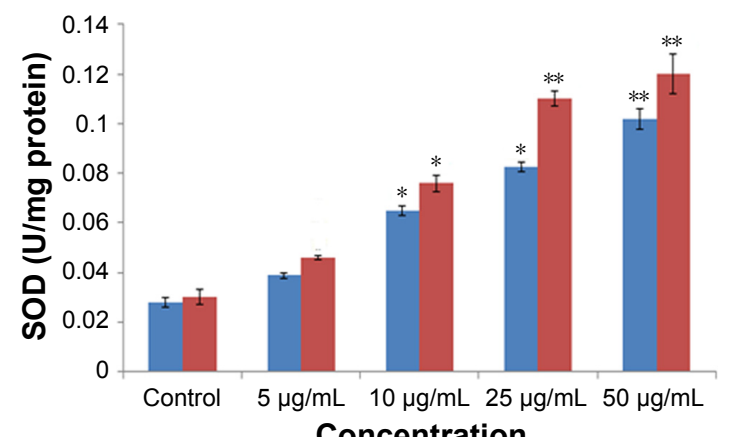

B

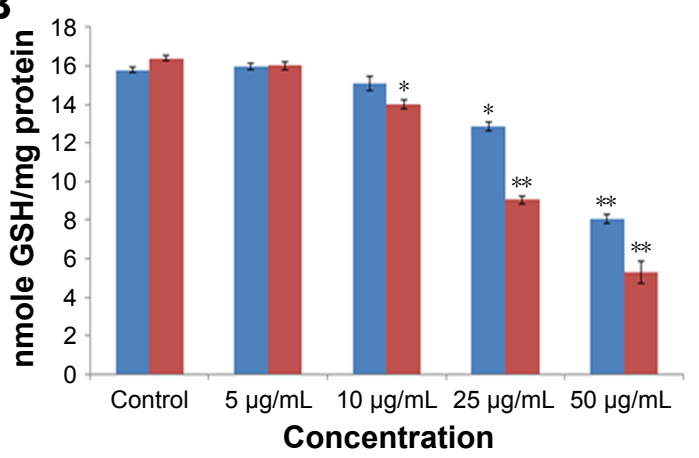

D

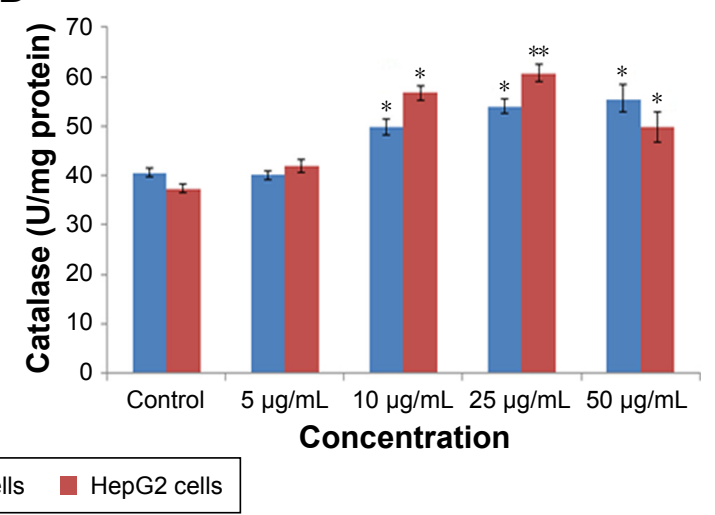

Figure 5 (A) Levels of LPO, (B) GSH, and (C) SOD. (D) Catalase activity in CHANG and HepG2 cells after exposure to rGO-Ag nanocomposite for 24 h. Notes: Each value represents the mean \pm SE of three experiments. ${ }^{*} p<0.05$ and $* * p<0.01$ vs control.

Abbreviations: $\mathrm{rGO}-\mathrm{Ag}$, silver-doped reduced graphene oxide; GSH, glutathione; LPO, lipid peroxide; MDA, malondialdehyde; SE, standard error; SOD, superoxide dismutase.

The apoptotic and necrotic effects of rGO-Ag nanocomposite in CHANG and HepG2 cells were studied by using Annexin V-FITC assay. In this experiment, the CHANG and $\mathrm{HepG} 2$ cells were exposed to $\mathrm{rGO}-\mathrm{Ag}$ nanocomposite for $24 \mathrm{~h}$ at $50 \mu \mathrm{g} / \mathrm{mL}$ concentration to examine the apoptotic effect. The results, as shown in Figure 8, suggest that the rGO-Ag nanocomposite induced significant apoptosis in CHANG and HepG2 cells. The caspase-3 gene was highly expressed in the exposed cells compared with control cells (Figure 9).

\section{DNA damage}

The strand breakage of DNA in both the cells after rGO-Ag nanocomposite exposure was determined as olive tail moment and \% tail DNA in the control and exposed cells. CHANG and HepG2 cells were treated with rGO-Ag nanocomposite, and it expressed maximum DNA strand breakage in exposed cells compared with control cells (Figure 10).

\section{Effects of NAC on cytotoxicity and ROS generation}

To confirm the role of ROS generation in the induction of cytotoxicity of rGO-Ag nanocomposite, $\mathrm{CHANG}$ and
HepG2 cells were treated with $\mathrm{rGO}-\mathrm{Ag}$ nanocomposite $(50 \mu \mathrm{g} / \mathrm{mL})$ in the presence of NAC, a potent ROS hunter. Our data indicated that that NAC significantly inhibited the production of ROS (Figure 4B) and ended near about the cytotoxicity of the rGO-Ag nanocomposite in CHANG and HepG2 cells (Figure 11).

\section{Discussion}

Graphene has been found useful in the field of bone tissue applications and drug delivery. The size of graphene oxide affects its application in drug carrier. The large size of rGO hinders drug delivery in the bloodstream. Mendonça et $\mathrm{a}^{28}$ reported that small-size graphene oxide is easily phagocytosed and more applicable for drug loading. In this study, we used rGo-Ag nanocomposite. The adverse effects of engineered nanoparticles have been considered as a serious limitation for their different applications, and so, the toxicological characterization of these nanoparticles is essential before application of these nanoparticles.

Murdock et a $\mathrm{l}^{14}$ suggested that nanomaterials produced adverse effects due to their chemical nature and size. Therefore, it is obligatory to find out the properties of the rGO-Ag nanocomposite prior to its biological application. 

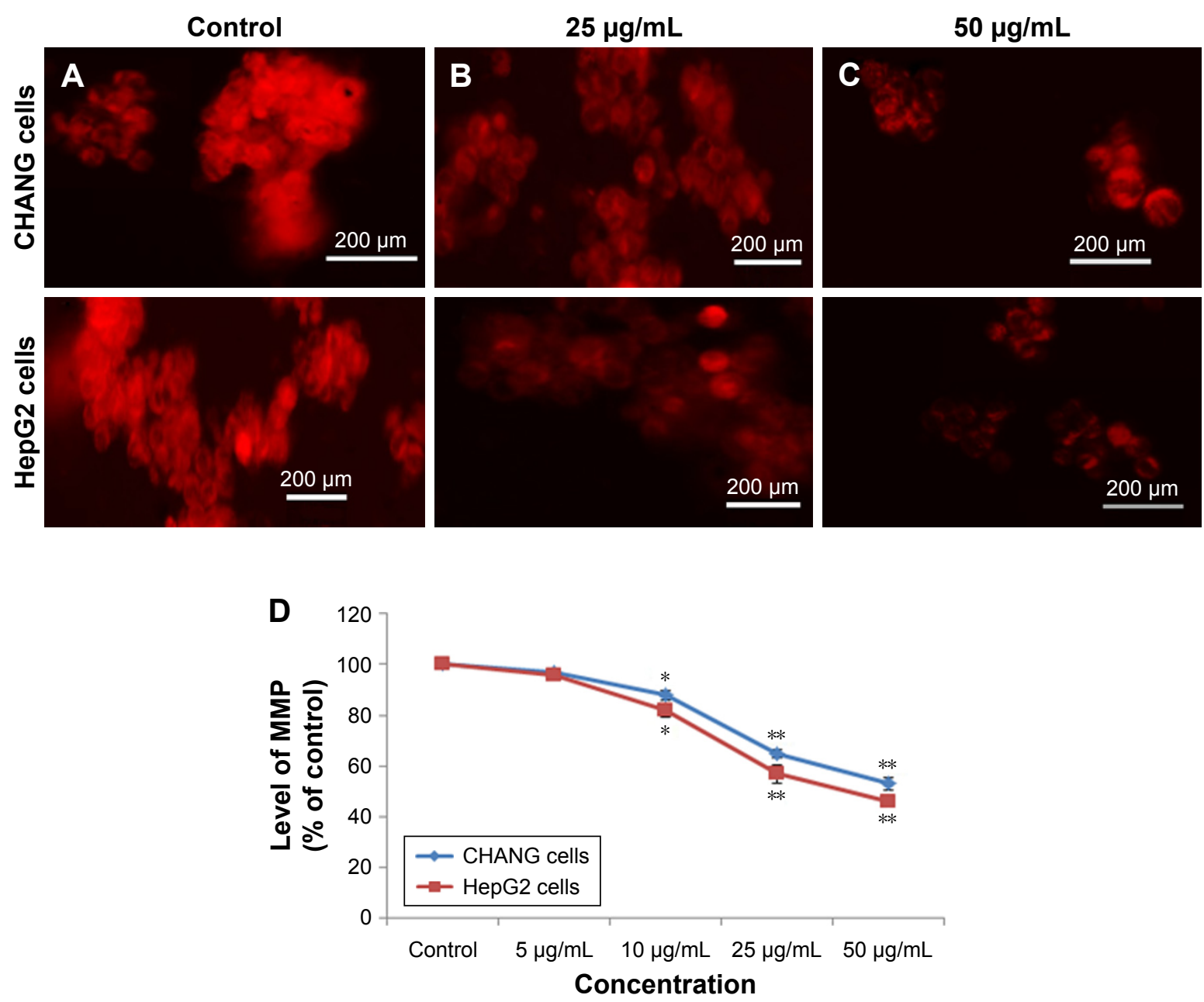

Figure 6 Images representing MMP loss in CHANG and HepG2 cells after rGO-Ag nanocomposite exposure at concentrations of 25 and $50 \mu g / m L$ for 24 h. Notes: (A) Control cells. (B) rGO-Ag nanocomposite exposure, $25 \mu \mathrm{g} / \mathrm{mL}$ for $24 \mathrm{~h}$ and (C) $50 \mu \mathrm{g} / \mathrm{mL}$ for $24 \mathrm{~h}$. (D) Change in MMP (\%) in CHANG and HepG2 cells after rGO-Ag nanocomposite exposure for $24 \mathrm{~h}$. Each value represents the mean \pm SE of three experiments. ${ }^{*} p<0.05$ and $* * p<0.01$ vs control. Abbreviations: $\mathrm{rGO}-\mathrm{Ag}$, silver-doped reduced graphene oxide; MMP, mitochondrial membrane potential; SE, standard error.

The main parameters of a nanocomposite are its purity, crystalline nature, shape, size, hydrodynamic size, and clumping, which control the biological activities of the nanocomposite..$^{25,29}$ We have determined the size of the rGO-Ag nanocomposite by DLS, SEM, and TEM methods. The greater size of nanocomposite in liquid suspension in comparison to the primary size is due to aggregation of nanocomposite in liquid. ${ }^{30}$

The larger diameter of the nanocomposite in water suspension than the basic diameter might be due to the tendency of nanocomposite to clump in aqueous suspension. ${ }^{31}$ Wang et $\mathrm{al}^{32}$ reported that nanoparticles interact with proteins of culture medium and construct a protein layer (corona). Therefore, not only the size of the primary nanoparticles but also the size of the secondary nanoparticles could be used as a characteristic parameter to determine the in vitro toxicity of nanoparticles in a cell culture medium. ${ }^{33}$ The TEM images revealed the transparent and sheet-like structure of chemically reduced graphene oxide. An enormous number of scrolls and wrinkles were observed on the surface of the chemically reduced graphene oxide. The GO sheet remains stable under the high-energy electron beam. It has been noticed that the edges of the suspended graphene layers were folded back, and thickness of few-layer in chemically reduced graphene.

Furthermore, the cytotoxicity and apoptotic effect of the rGO-Ag nanocomposite on CHANG and $\mathrm{HepG} 2$ cells were detected by using MTT, LDH, and DNA fragment assay. The rGO-Ag nanocomposite reduced cell growth in a concentration-dependent manner in CHANG and HepG2 cells. The cytotoxicity tests used were MTT (mitochondrial function) and membrane integrity (LDH leakage). These 
A
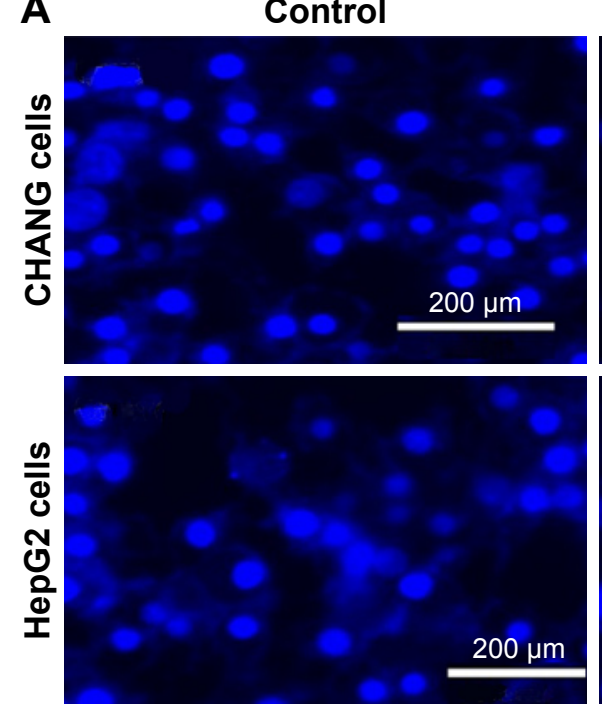

\section{B}

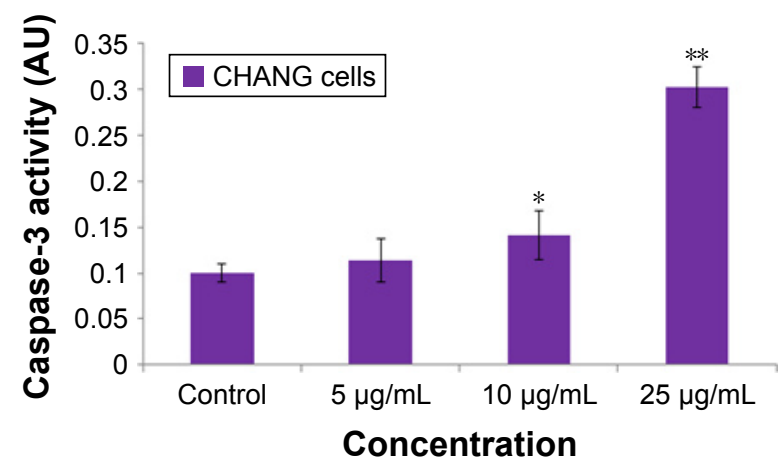

$25 \mu \mathrm{g} / \mathrm{mL}$
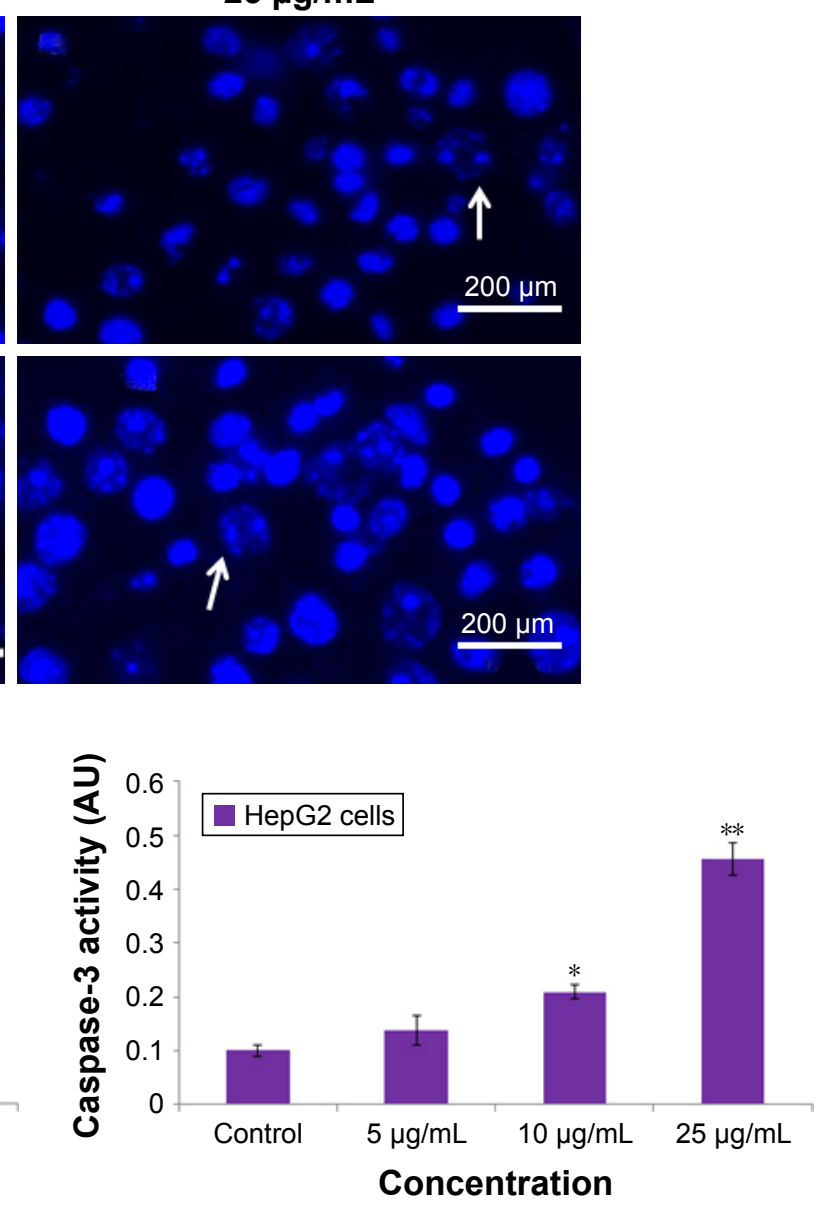

Figure 7 (A) Chromosomal condensation and (B) induction of caspase-3 activity in CHANG and HepG2 cells after exposure to rGO-Ag nanocomposite for 24 h. Notes: Each value represents the mean \pm SE of three experiments. ${ }^{*} p<0.05$ and $* * p<0.01$ vs control. Arrows indicate fragmented chromosome. Abbreviations: $\mathrm{rGO}-\mathrm{Ag}$, silver-doped reduced graphene oxide; $\mathrm{SE}$, standard error.

tests served as a sensitive and integrated examination of cell integrity and inhibition of cell growth. Cells were stained with Hoechst stains, and significantly fragmented nuclei were observed in both the nanocomposite-exposed cells. In the control cells without treatment, the cell nuclei were round intact shape.

To confirm whether prevention of cell growth was induced by the apoptotic/necrotic activity, we used AnnexinV-FITC and PI fluorescence stains for analyzing apoptotic and necrotic cells by FACS (BD FACSCanto ${ }^{\text {TM }}$ II flow cytometry analyzer systems; BD Biosciences, San Jose, CA, USA) and observed that relevant $\mathrm{rGO}-\mathrm{Ag}$ nanocomposite induced a much higher apoptosis cell rate than the untreated cells. In CHANG/HepG2 cells treated with rGO-Ag nanocomposite, the percentage of DNA damage in comet tail was much higher than that observed in untreated cells. Our observations supported the hypothesis that the remarkable enhancement of apoptosis was induced by the synergistic effect of the $\mathrm{rGO}-\mathrm{Ag}$ nanocomposite. We measured apoptotic enzyme activity as caspase-3 in CHANG/ HepG2 cells after exposure to $\mathrm{rGO}-\mathrm{Ag}$ nanocomposite. The caspase- 3 activity increased in a dose-dependent manner.

Oxidative stress generated by ROS is linked to the activation of caspase pathway. The activation of caspase-3 leads to fundamentally different cellular responses, including proliferation, differentiation, survival, and death. Castiglioni et $\mathrm{al}^{34}$ reported that in some types of cells (T24 cells), antioxidants do not inhibit cytotoxicity, thus suggesting that different mechanisms are responsible for cell toxicity in different cells. For the first time in normal hepatic cells, we present evidence that the $\mathrm{CGO}-\mathrm{Ag}$ nanocomposite is toxic in a dose-dependent fashion through the activation of the ROS and caspase-3 signaling pathway, which leads to the death of the cells. MTT, LDH assay, and FACS demonstrate the toxicity and the induction of apoptosis by rGO-Ag nanocomposite in CHANG and HepG2 cells. 
A

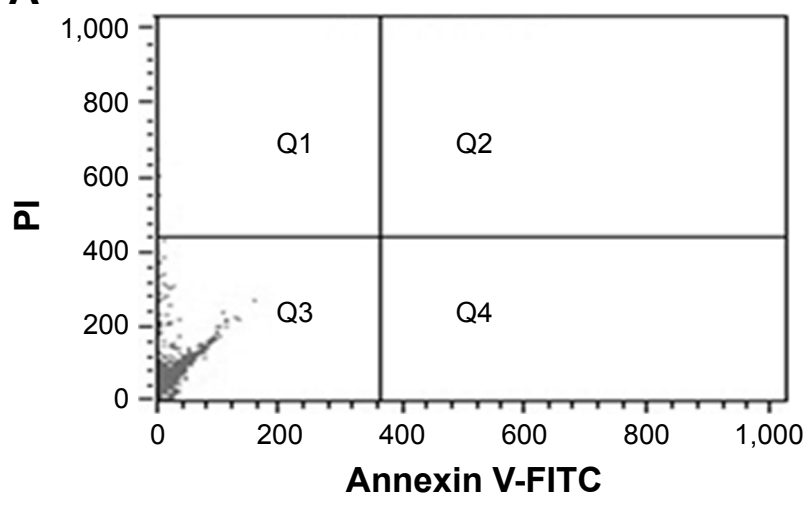

C

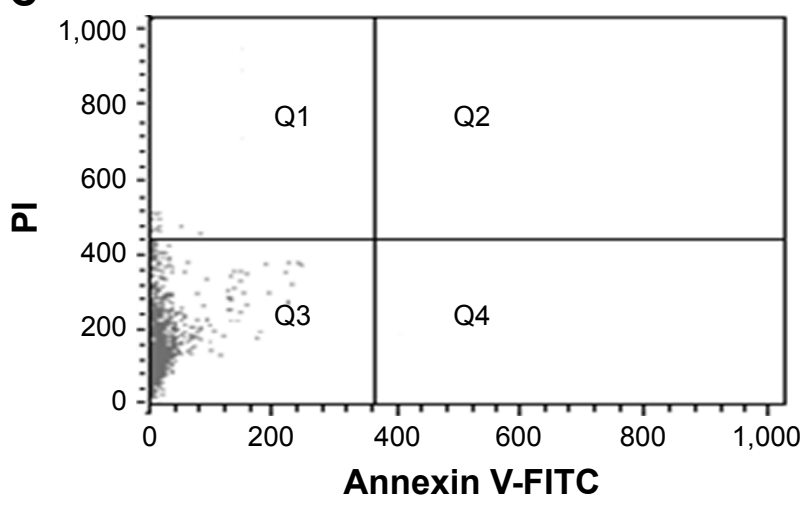

E

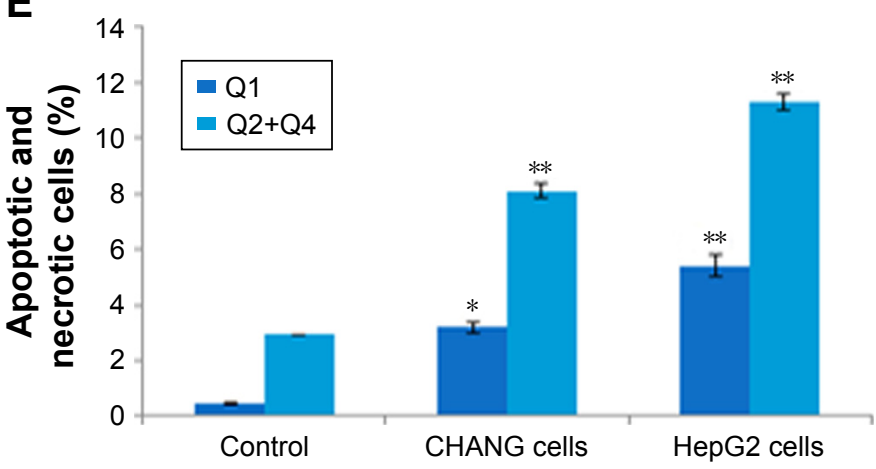

B

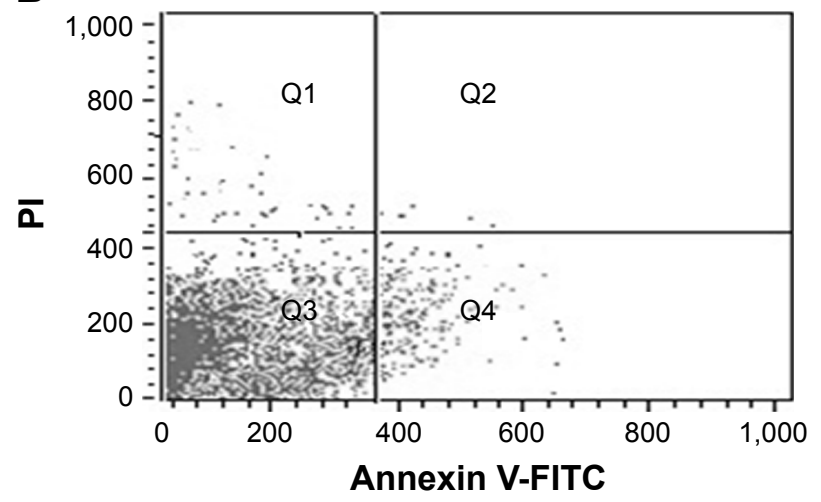

D

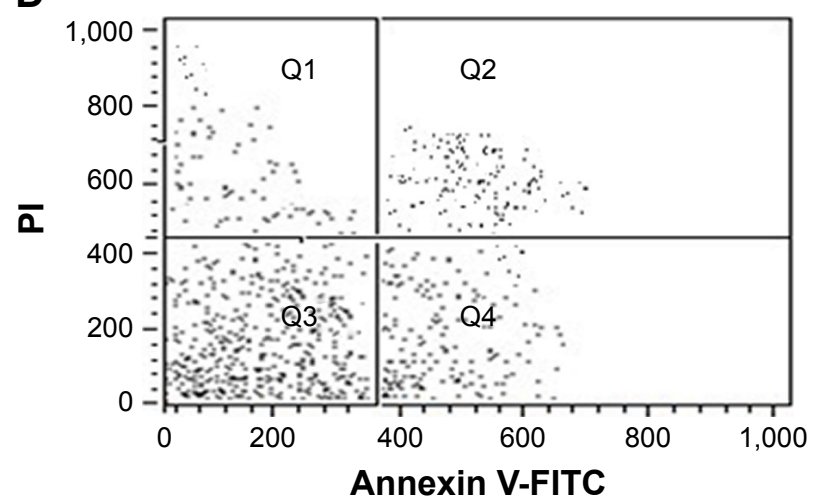

Annexin V-FITC

Notes: Annexin V-FITC and PI fluorescence were measured using flow cytometer with PI and Annexin V-FITC filters, respectively. (A) Control (CHANG cells). (B) rGO-Ag nanocomposite $(25 \mu \mathrm{g} / \mathrm{mL}$ )-exposed CHANG cells. (C) Control (HepG2 cells). (D) rGO-Ag nanocomposite (25 $\mu \mathrm{g} / \mathrm{mL})$-exposed HepG2 cells. (E) Percentage of apoptotic

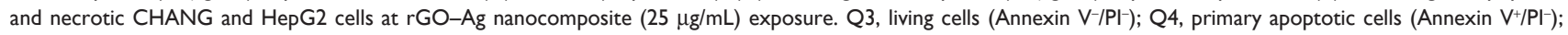
$\mathrm{Q} 2$, late apoptotic and secondary apoptotic cells $\left(\right.$ Annexin $\left.\mathrm{V}^{+} / \mathrm{PI}^{+}\right)$; $\mathrm{QI}$, necrotic cells $\left(\right.$ Annexin $\left.\mathrm{V}^{-} / \mathrm{PI}^{+}\right)$. Data represent average $\pm \mathrm{SE}$ of triplicate experiments. $* p<0.05$ and $* * p<0.01$ compared to control.

Abbreviations: $\mathrm{rGO}-\mathrm{Ag}$, silver-doped reduced graphene oxide; $\mathrm{Pl}$, propidium iodide; SE, standard error.

In numerous biochemical studies, it has been established that most tumor cells present very few antioxidative enzymes, such as CAT, SOD, and GSH peroxidase, which are known to play a protective role against ROS in normal cells. An early and remarkable effect of the $\mathrm{rGO}-\mathrm{Ag}$ nanocomposite on the cells is the alteration of cell shape. Indeed, after $24 \mathrm{~h}$ of exposure to $\mathrm{rGO}-\mathrm{Ag}$ nanocomposite, morphological alterations were clearly detectable. The cells lost their typical spindle shape and the cytoskeleton was disorganized, despite the evidence that the total content of actin did not vary. Moreover, some fragmented nuclei, a typical feature of apoptosis, could be observed. It is noteworthy that the reorganization of the cytoskeleton is a necessary event in apoptosis. Reshetnikova et $\mathrm{al}^{35}$ suggested that cytochalasin D 


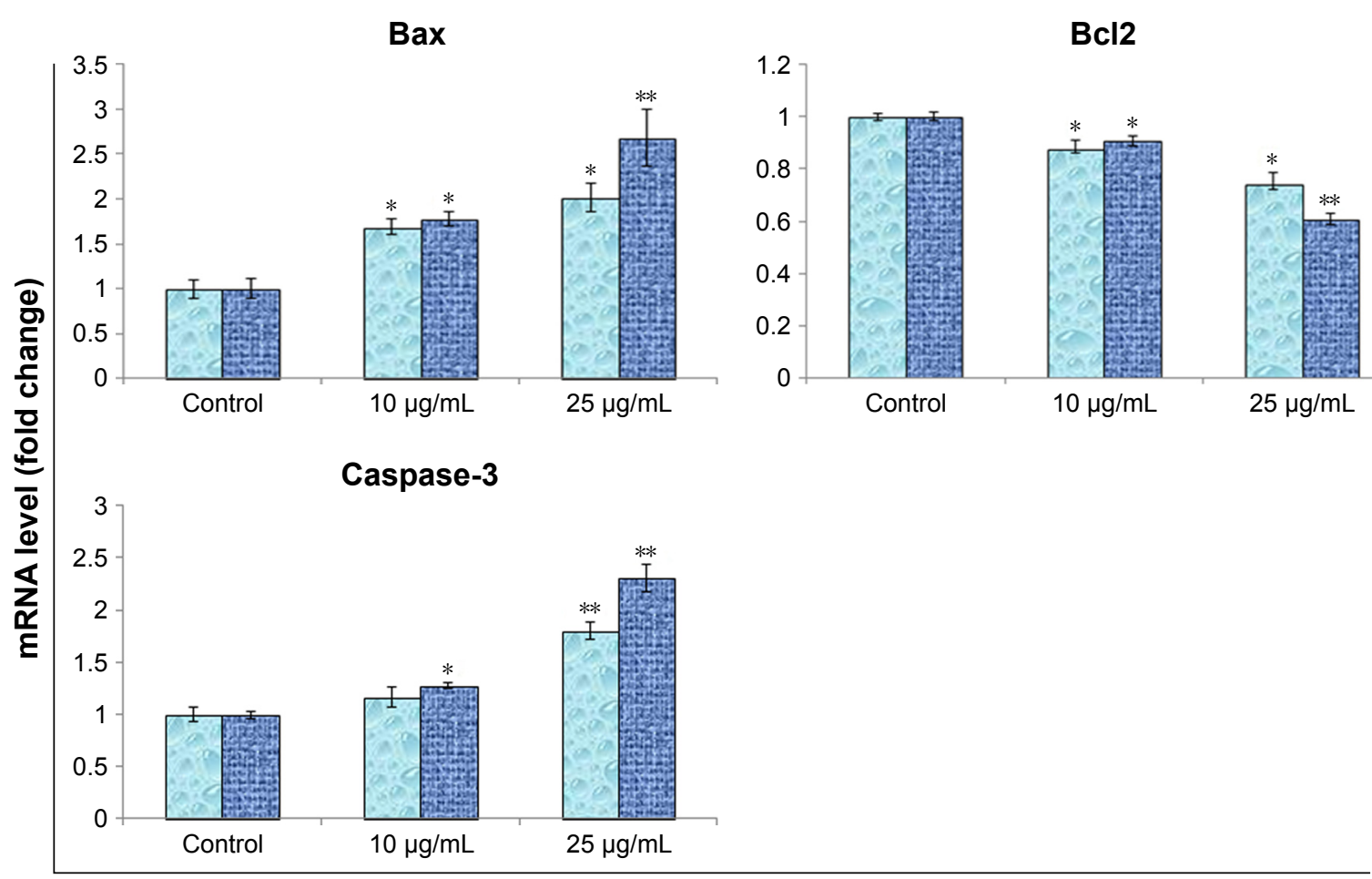

rGO-Ag nanocomposite

$\square$ CHANG cells m HepG2 cells

Figure 9 Quantitative real-time PCR analysis of mRNA levels of apoptotic genes in CHANG and HepG2 cells exposed to rGO-Ag nanocomposite for 24 h. Notes: Results are expressed as average \pm SE of triplicate experiments. $*_{p}<0.05$ and $* * p<0.01$ compared to control.

Abbreviations: $\mathrm{rGO}-\mathrm{Ag}$, silver-doped reduced graphene oxide; PCR, polymerase chain reaction; SE, standard error.

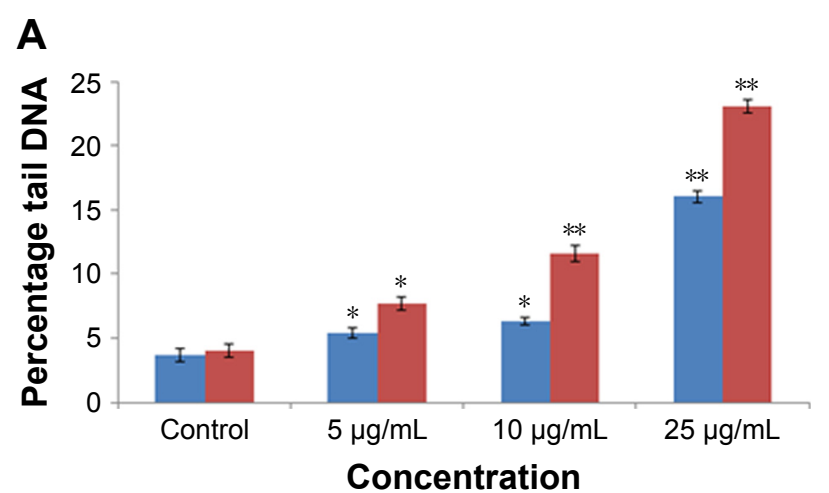

CHANG cells
B

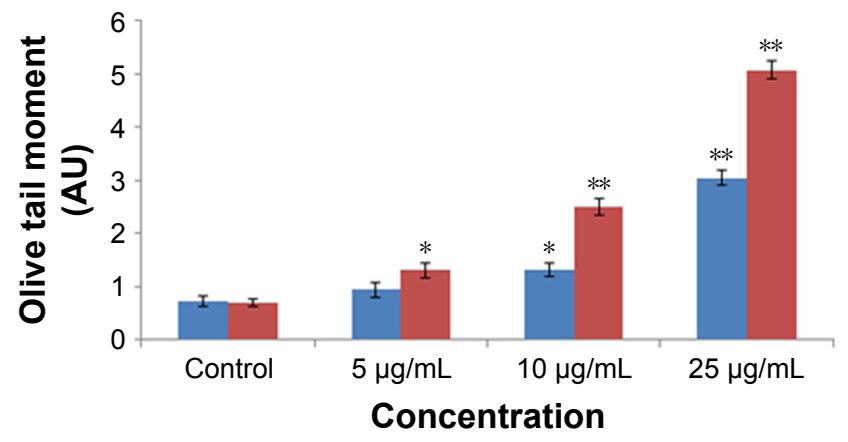

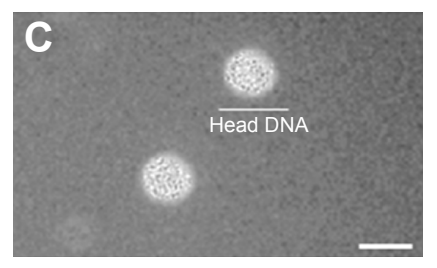
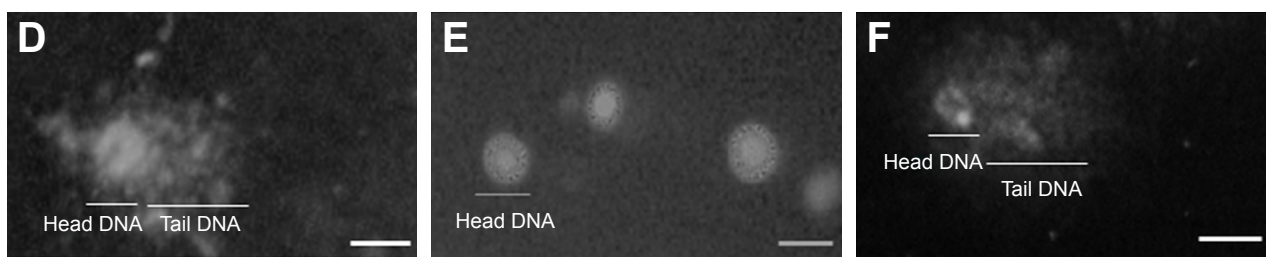

Figure 10 DNA strand breakage in CHANG and HepG2 cells due to the $\mathrm{rGO}-\mathrm{Ag}$ nanocomposite.

Notes: (A) Tail DNA (\%). (B) Olive tail moment. (C) Untreated (CHANG) cell. (D) Treated CHANG cell (25 $\mu g / m L$ of rGO-Ag nanocomposite). (E) Untreated (HepG2) cell. (F) Treated HepG2 cell $\left(25 \mu \mathrm{g} / \mathrm{mL}\right.$ of $\mathrm{rGO}-\mathrm{Ag}$ nanocomposite). Each value represents the mean \pm SE of three experiments. ${ }^{*} p<0.05$ and $* * p<0.0 \mathrm{I}$ vs control. Scale bar $=50 \mu \mathrm{m}$.

Abbreviations: $\mathrm{rGO}-\mathrm{Ag}$, silver-doped reduced graphene oxide; $\mathrm{SE}$, standard error. 


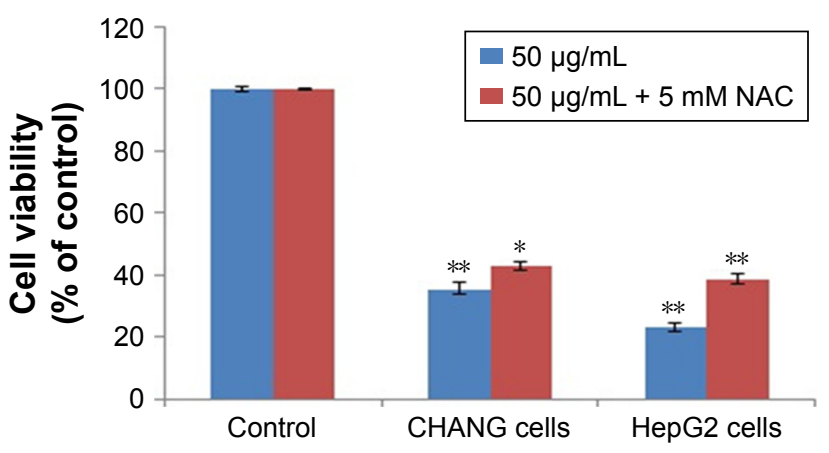

Figure II CHANG and HepG2 cells were exposed to rGO-Ag nanocomposite $(50 \mu \mathrm{g} / \mathrm{mL})$ in the presence of $5 \mathrm{mM} \mathrm{NAC}$ for $24 \mathrm{~h}$.

Notes: NAC significantly reversed the viability (MTT assay) of CHANG and HepG2 cells caused by the $\mathrm{rGO}-\mathrm{Ag}$ nanocomposite. Each value represents the mean $\pm \mathrm{SE}$ of three experiments. $n=3, * p<0.05$ and $* * p<0.01$ vs control.

Abbreviations: $\mathrm{rGO}-\mathrm{Ag}$, silver-doped reduced graphene oxide; NAC, $\mathrm{N}$-acetylcysteine; SE, standard error.

induces apoptosis due to depolymerization of actin filaments in cells.

We found the levels of LPO, SOD, and CAT were raised and GSH level was dropped in both the cells due to the exposure to $\mathrm{rGO}-\mathrm{Ag}$ nanocomposite, which demonstrates oxidized stress of cells. LPO enzyme generates more free radicals and damages the biomolecules with ROS. Ott et $\mathrm{al}^{26}$ reported that too much ROS generation initiates apoptosis. The rGO-Ag nanocomposite induced apoptosis in epithelial ovarian carcinoma cells. ${ }^{36}$ The DNA damage and the oxidative stress observed in the present study are in accordance with the findings of Alarifi et $\mathrm{a}^{37}$ in the human hepatocarcinoma cells for palladium nanoparticles and with Alkahtane ${ }^{38}$ in the A549 for indium tin oxide nanoparticles.

We have found that rGO-Ag nanocomposite induced cytotoxicity in human hepatic normal and cancerous cells in a dose-dependent manner. The $\mathrm{rGO}-\mathrm{Ag}$ nanocomposite induced apoptosis and oxidative stress in a dose-dependent basis, as confirmed by the increase in ROS generation and LPO and decrease in GSH. In this study, we found that HepG2 cells were slightly more susceptible to nanocomposite than the CHANG cells. More examinations are underway to find the toxic mechanisms of $\mathrm{rGO}-\mathrm{Ag}$ nanocomposite at in vivo level.

\section{Acknowledgment}

The authors would like to extend their sincere appreciation to the Deanship of Scientific Research at King Saud University for its funding of this research through the Research Group Project No RGP-180.

\section{Disclosure}

The authors report no conflicts of interest in this work.

\section{References}

1. Zhang X-F, Liu Z-G, Shen W, Gurunathan S. Silver nanoparticles: Synthesis, characterization, properties, applications, and therapeutic approaches. Int J Mol Sci. 2016;17(9):1534.

2. La WG, Jin M, Park S, et al. Delivery of bone morphogenetic protein-2 and substance $\mathrm{P}$ using graphene oxide for bone regeneration. Int $J$ Nanomedicine. 2014;9(1):107-116.

3. Goncalves G, Cruz SM, Ramalho A, Gracio J, Marques PA. Graphene oxide versus functionalized carbon nanotubes as a reinforcing agent in a PMMA/HA bone cement. Nanoscale. 2012;4(9):2937-2945.

4. Ma H, Zhang X, Li X, Li R, Du B, Wei Q. Electrochemical immunesensor for detecting typical bladder cancer biomarker based on reduced graphene oxide-tetra ethylene pentamine and trimetallic Au PdPt nanoparticles. Talanta. 2015;143:77-82.

5. Al-Ogaidi I, Gou H, Aguilar ZP, et al. Detection of the ovarian cancer biomarker CA-125 using chemiluminescence resonance energy transfer to graphene quantum dots. Chem Commun. 2014;50:1344-1346.

6. Gurunathan S, Han JW, Park JH, Eppakayala V, Kim JH. Ginkgo biloba: a natural reducing agent for the synthesis of cytocompatible graphene. Int J Nanomedicine. 2014;9:363-377.

7. Zhu YG, Cao GS, Sun CY, et al. Design and synthesis of NiO nanoflakes/graphene nanocomposite as high performance electrodes of pseudo capacitor. RSC Adv. 2013;3(42):19409-19415.

8. Chook SW, Chia CH, Zakaria S, et al. Antibacterial performance of Ag nanoparticles and Ag-GO nanocomposites prepared via rapid microwave-assisted synthesis method. Nanoscale Res Lett. 2012;7(1):541.

9. Pasricha R, Gupta S, Srivastava AK. A facile and novel synthesis of Ag-graphene-based nanocomposites. Smal. 2009;5(20):2253-2259.

10. Xia T, Kovochich M, Liong M, Zink JI, Nel AE. Cationic polystyrene nanosphere toxicity depends on cell-specific endocytic and mitochondrial injury pathways. ACS Nano. 2008;2(1):85-96.

11. AshaRani P, Sethu S, Lim HK, Balaji G, Valiyaveettil S, Hande MP. Differential regulation of intracellular factors mediating cell cycle, DNA repair and inflammation following exposure to silver nanoparticles in human cells. Genome Integr. 2012;3(1):2.

12. Han JW, Gurunathan S, Jeong JK, et al. Oxidative stress mediated cytotoxicity of biologically synthesized silver nanoparticles in human lung epithelial adenocarcinoma cell line. Nanoscale Res Lett. 2014; 9(1):459.

13. Carlson C, Hussain SM, Schrand AM, et al. Unique cellular interaction of silver nanoparticles: size-dependent generation of reactive oxygen species. J Phys Chem B. 2008;112(43):13608-13619.

14. Murdock RC, Braydich-Stolle L, Schrand AM, Schlager JJ, Hussain SM. Characterization of nanomaterial dispersion in solution prior to in vitro exposure using dynamic light scattering technique. Toxicol Sci. 2008;101(2):239-253.

15. Mosmann T. Rapid colorimetric assay for cellular growth and survival: application to proliferation and cytotoxicity assays. J Immunol Meth. 1983;65:55-63.

16. Alarifi S, Ali D, Verma A, Alakhtani S, Ali BA. Cytotoxicity and genotoxicity of copper oxide nanoparticles in human skin keratinocytes cells. Int J Toxicol. 2013;32(4):296-307.

17. Alarifi S, Ali D, Alkahtani S. Nanoalumina induces apoptosis by impairing antioxidant enzyme systems in human hepatocarcinoma cells. Int J Nanomedicine. 2015;10(1):3751-3760.

18. Ohkawa H, Onishi N, Yagi K. Assay for lipid peroxidation in animal tissue by thiobarbituric acid reaction. Anal Biochem. 1979;95:351-358.

19. Ellman GL. Tissue sulfhydryl groups. Arch Biochem Biophys. 1959; $82: 70-77$

20. Ali D, Alarifi S, Alkahtani S, AlKahtane AA, Almalik A. Cerium oxide nanoparticles induce oxidative stress and genotoxicity in human skin melanoma cells. Cell Biochem Biophys. 2015;71(3):1643-1651. 
21. Aebi H. Catalase. Methods Enzymol. 1984;105:121-126.

22. Sakamuru S, Attene-Ramos MS, Xia M. Mitochondrial membrane potential assay. Methods Mol Biol. 2016;1473:17-22.

23. Ali D, Nagpure N, Kumar S, Kumar R, Kushwaha B. Genotoxicity assessment of acute exposure of chlorpyrifos to freshwater fish Channa punctatus (Bloch) using micronucleus assay and alkaline single cell gel electrophoresis. Chemosphere. 2008;71:1823-1831.

24. Bradford MM. A rapid and sensitive method for the quantitation of microgram quantities of protein utilizing the principle of protein dye binding. Anal Biochem. 1976;72:248-254.

25. Nel A, Xia T, Madler L, et al. Toxic potential of materials at the nano level. Science. 2006;311:622-627.

26. Ott M, Gogvadze V, Orrenius S, Zhivotovsky B. Mitochondria, oxidative stress and cell death. Apoptosis. 2007;12:913-922.

27. Webster KA. Mitochondrial membrane permeabilization and cell death during myocardial infarction: roles of calcium and reactive oxygen species. Future Cardiol. 2012;8(6):863-884.

28. Mendonça MCP, Soares ES, de Jesus MB, et al. Reduced graphene oxide: nanotoxicological profile in rats. J Nanobiotechnology. 2016;14:53.

29. Yu J, Yang J, Liu B, Ma X. Preparation and characterization of glycerol plasticized-pea starch/ZnO-carboxymethyl cellulose sodium nanocomposites. Bioresour Technol. 2009;100:2832-2841.

30. Muller KH, Motskin M, Philpott AJ, et al. The effect of particle agglomeration on the formation of a surface-connected compartment induced by hydroxyapatite nanoparticles in human monocyte-derived macrophages. Biomaterials. 2014;35(3):1074-1088.
31. Bai W, Zhang Z, Tian W, He X, Ma Y, et al. Toxicity of zinc oxide nanoparticles to zebrafish embryo: A physicochemical study of toxicity mechanism. J Nanopart Res. 2009;12:1645-1654.

32. Wang H, Lin Y, Nienhaus K, Nienhaus GU. The protein corona on nanoparticles as viewed from a nanoparticle-sizing perspective. Wiley Interdiscip Rev Nanomed Nanobiotechnol. Epub 2017 Oct 26.

33. Yildirimer L, Thanhb NTK, Marilena L, Seifalian AM. Toxicological considerations of clinically applicable nanoparticles. Nano Today. 2011;6: 585-607.

34. Castiglioni S, Caspani C, Cazzaniga A, Maier JAM. Short and long term effects of silver nanoparticles on human micro vascular endothelial cells. World J Biol Chem. 2014;5(4):457-464.

35. Reshetnikova G, Barkan R, Popov B, Nikolsky N, Chang LS. Disruption of the actin cytoskeleton leads to inhibition of mitogen-induced cyclin E expression, CDK2 phosphorylation, and nuclear accumulation of the retinoblastoma protein-related p107 protein. Exp Cell Res. 2000;259:35-53

36. Gurunathan S, Woong J, Jung H, et al. Reduced graphene oxide silver nanoparticle nanocomposite: a potential anticancer nanotherapy. Int $J$ Nanomedicine. 2015:10:6257-6276.

37. Alarifi S, Ali D, Alkahtani S, Almeer RS. ROS-mediated apoptosis and genotoxicity induced by palladium nanoparticles in human skin malignant melanoma cells. Oxid Med Cell Longev. 2017;2017: 8439098.

38. Alkahtane AA. Indium tin oxide nanoparticles-mediated DNA fragmentation and cell death by apoptosis in human lung epithelial cells Toxicological and Environmental Chemistry. 2015;97(8):1086-1098.
International Journal of Nanomedicine

\section{Publish your work in this journal}

The International Journal of Nanomedicine is an international, peerreviewed journal focusing on the application of nanotechnology in diagnostics, therapeutics, and drug delivery systems throughout the biomedical field. This journal is indexed on PubMed Central, MedLine, CAS, SciSearch $®$, Current Contents $\AA /$ Clinical Medicine,

\section{Dovepress}

Journal Citation Reports/Science Edition, EMBase, Scopus and the Elsevier Bibliographic databases. The manuscript management system is completely online and includes a very quick and fair peer-review system, which is all easy to use. Visit http://www.dovepress.com/ testimonials.php to read real quotes from published authors. 